\title{
MODEL LEĆE: PROMOCIJA NEUROREZILIENCIJE I ZDRAVLJA MOZGA U STARIJOJ DOBI
}

\author{
Miro Jakovljević \\ Klinika za psihijatriju Medicinskog fakulteta Sveučilišta u Zagrebu, Klinički bolnički centar Zagreb
}

Autor za korespondenciju:

Miro Jakovljević

jakovljevic.miro@yahoo.com

primljen: 2019, prihvaćen: 2019, objavljen: 2020.

\section{Apstrakt}

Poticanje zdravog i uspješnog starenja i uključenosti starijih osoba u društvene aktivnosti, odnosno učinkovita prevencija negativnih posljedica starenja, iznimno je važna ne samo medicinska i humanistička već i socijalna, ekonomska i politička tema. Promjene mozga koje počinju u pedesetim godinama života ne oštećuju samo pamćenje nego i druge kognitivne funkcije, kao što su naša sposobnost obavljanja više radnji, brzo procesiranje informacija i usmjeravanje pažnje na detalje, a smanjuje se i naša kreativnost, kvaliteta življenja, životna energija i želja za životom. Mnogo je pogrešnih stavova i iskrivljenih mišljenja o mozgu i starenju. Gerontologija se sve više usmjerava na prepoznavanje specifičnih kvaliteta i sposobnosti starijih osoba i njihov mogući doprinos zajednici i društvu. Reziliencija predstavlja skup zaštitnih i salutogenih (kako neurobioloških tako i psihosocijalnih i spiritualnih) čimbenika koji moduliraju pozitivne ishode u stresnim i nepovoljnim situacijama, tijekom starenja i u bolesti. Do unazad dva-tri desetljeća vjerovalo se da naš mozak stvara nove neurone samo u ranoj mladosti. Međutim, istraživanja pokazuju da mozak zahvaljujući svojoj neuroplastičnosti ima sposobnost mijenjati se tijekom cijelog života stvaranjem novih neurona i veza između njih pa čak i povećati svoju veličinu. Naše spoznaje o neuroplastičnosti mozga u stalnom su porastu, a povećanje reziliencije našeg mozga veliki je izazov za temeljne i kliničke neuroznanosti. Individualna SSPP (Snaga, Slabost, Prilike, Prijetnje) analiza, koja uključuje jedinstvene resurse i perspektive ljubavi, moći, slobode, sreće i smisla, predstavlja model leće kroz koju se prelamaju izazovi starije životne dobi i predviđa uspješno starenje. U tekstu se prikazuje model leće za uspješno starenje kroz promociju reziliencije.

Ključne riječi: model leće, neuroreziliencija, zdravlje mozga, uspješno starenje. 


\section{Uvod}

Poticanje zdravog i uspješnog starenja i uključenosti starijih osoba u društvene aktivnosti, odnosno učinkovita prevencija negativnih posljedica starenja, iznimno je važna ne samo medicinska i humanistička već i socijalna, ekonomska i politička tema. Svima nam je želja da doživimo starost i dalje je živimo u dobrom zdravlju i veselju, a što nazivamo uspješno starenje. Uspješno starenje predstavlja jedan od ključnih pojmova suvremene gerontologije. Pojmovi slični uspješnom starenju su vitalno starenje, aktivno starenje, produktivno starenje, pozitivno starenje, normalno starenje, zdravo starenje... Zdravo se starenje definira na temelju odsustva bolesti, odnosno kvalitete zdravlja, normalno starenje mjeri se statističkim normama, produktivno starenje stupnjem doprinosa zajednici, aktivno starenje na temelju aktivnog pristupa života, vitalno starenje stupnjem vitaliteta, životnosti i životne odgovornosti. Uspješno starenje uključuje pojmove kao što su životno zadovoljstvo, dugovječnost, odsustvo dizabiliteta, upravljanje sobom i svojim životom (personal mastery), samostalnost i neovisnost, aktivna uključenost u život (1). Uspješno starenje je zapravo poželjno starenje kojemu treba težiti kako na osobnoj tako i na kolektivnoj, odnosno široj društvenoj razini. Nasuprot uspješnom starenju najčešće se postavlja uobičajeno starenje i abnormalno ili patološko starenje. Prema Svjetskoj zdravstvenoj organizaciji (2) aktivno starenje je proces optimizacije povoljnih prigoda za zdravlje, sudjelovanje u životu i sigurnost s namjerom da se poveća kvaliteta života starijih osoba. Kada adaptacija rezultira mogućnošću neke osobe da ostvaruje svoje željene ciljeve, naziva se uspješnim starenjem. Drugim riječima, uspješno starenje je zdravo starenje, aktivno starenje, pozitivno starenje, produktivno starenje, sretno starenje, vitalno starenje. S druge strane, zdravo starenje je uspješno starenje, aktivno starenje, pozitivno starenje, sretno starenje itd.

\section{Zdravo starenje kao odsustvo bolesti ili kao subjektivna dobrobit i oblik sreće}

Zdravlje je najveće bogatstvo, kaže narodna poslovica, jer zdrav čovjek ima tisuće želja, a bolestan samo jednu: da ozdravi. To isto vrijedi i za osobe u starijoj životnoj dobi. Nema zdravlja bez duševnog zdravlja i duševno zdravlje je iznimno važno, kako iz individualne tako i iz društvene perspektive. Često se može čuti kako "zdravo društvo čine zdravi ljudi" te kako na "mladima svijet ostaje", pri čemu neki mudro dodaju "a na starijima opstaje". Tijekom povijesti na starenje se gledalo kroz različite leće, kao što su različiti odgovori 
na pitanja zašto i kako starimo o čemu postoje brojne teorije (vidjeti tab. 1). Neki su koncepti primarno usmjereni na fizičke i biološke aspekte, a drugi na psihosocijalne aspekte koji određuju uspješno starenje, dok ih treći integriraju u biopsihosocijalni model sa spiritualnom dimenzijom ili bez nje.

Tablica 1. Teorije starenja $(3,4)$

\begin{tabular}{|c|c|}
\hline \multirow{5}{*}{ 1. Biološke teorije } & $\begin{array}{l}\text { Evolucijske teorije (teorija nakupljanja mutacija, antagonistička pleiotropna teorija, teorija } \\
\text { nemogućnosti reparacije oštećenja i istrošenosti) }\end{array}$ \\
\hline & $\begin{array}{l}\text { Teorija slobodnih radikala (slobodni radikali koji dovode do oštećenja stanica uzrok su } \\
\text { starenja) }\end{array}$ \\
\hline & $\begin{array}{l}\text { Teorija skraćivanja telomera i smanjenja broja stanica (kada se telomere jako skrate, } \\
\text { sinteza DNA i dioba stanica ne mogu se više odvijati) (5) }\end{array}$ \\
\hline & Teorija kontrolirajućih gena \\
\hline & $\begin{array}{l}\text { Teorija akumulacije pogreški i oštećenja (na molekularnoj i staničnoj razini dolazi do } \\
\text { oštećenja koja se vremenom više ne mogu reparirati) }\end{array}$ \\
\hline \multirow{3}{*}{ 2. Fizičke teorije } & $\begin{array}{l}\text { Teorija gubitka kompleksnosti sustava (zbog slabljenja i zakazivanja komunikacije između } \\
\text { supsistema dolazi do degeneracije stanica/tkiva i komunikacijskog kaosa između njih) }\end{array}$ \\
\hline & $\begin{array}{l}\text { Teorija entropijskog rasta (porast entropije praćen je smanjenjem složenosti i } \\
\text { funkcionalnosti sustava) }\end{array}$ \\
\hline & $\begin{array}{l}\text { Teorija oštećenja informacijske transmisije i multicelularnog kaosa (vremenom prijenos } \\
\text { signala/informacija postaje kaotičan, zbog čega nastaje poremećaj u diferencijaciji i } \\
\text { organizaciji stanica }\end{array}$ \\
\hline \multirow{3}{*}{ 3. Psihološke teorije } & Eriksonova teorija psihosocijalnog razvoja i kriza (integritet vs. očaj) \\
\hline & $\begin{array}{l}\text { Peckova teorija psiholoških stadija u drugoj polovici života (1. stadij - diferencijacija ega } \\
\text { vs. preokupacija radnom ulogom; } 2 \text {. transcendencija tijela vs. preokupacija tijelom; } 3 \text {. } \\
\text { transcendencija ega vs. preokupacija tijelom) }\end{array}$ \\
\hline & $\begin{array}{l}\text { Fisherova teorija } 05 \text { stadija nakon umirovljenja (1. stadij - kontinuitet sa srednjom dobi; } \\
\text { 2. stadij rane tranzicije; } 3 \text {. preispitivanje ili revizija životnog stila; } 4 \text {. stadij kasnije tranzicije } \\
\text { i 5. završno razdoblje) }\end{array}$ \\
\hline \multirow[b]{2}{*}{ 4. Socijalne teorije } & Teorija aktiviteta (aktivnost u starijoj dobi podupire zdravlje) \\
\hline & $\begin{array}{l}\text { Teorija kontinuiteta (nastavak života pozitivno u svom unutarnjem svijetu i društvenim } \\
\text { relacijama) }\end{array}$ \\
\hline $\begin{array}{l}\text { 5. Kombinirane } \\
\text { biopsihosocijalne teorije }\end{array}$ & \\
\hline
\end{tabular}

Zdravo starenje prema starijim medicinskim konceptima temeljilo se na zdravom stilu življenja, odsustvu bolesti i zadovoljavajućoj funkcionalnosti. Danas se duševno zdravlje definira ne samo kao odsustvo duševnog poremećaja ili bolesti već i kao tjelesno, psihološko, socijalno i duhovno blagostanje i osjećaj dobrobiti. Sreća se također može definirati kao blagostanje i osjećaj 
dobrobiti. Još su tridesetih godina prošlog stoljeća američki psihijatri Nelson A. Crawford i Karl Menninger definirali duševno zdravlje kao "prilagođenost ljudi na svijet i jednih na druge uz maksimum efikasnosti i sreće". Prema Svjetskoj zdravstvenoj organizaciji (6), duševno zdravlje je stanje dobrobiti i blagostanja kada osoba realizira svoje potencijale, može se nositi s normalnim životnim stresovima, može raditi produktivno i uspješno i pridonositi dobrobiti svoje zajednice. Osjećaj blagostanja i dobrobiti ima svoju hedonističku (zadovoljstvo, životna radost) i svoju eudaimonijsku (živjeti dobro i realizirati autentične potencijale) dimenziju. Međutim, treba uvijek imati na umu kako ne odražava svaka sreća blagostanje i dobrobit, odnosno duševno zdravlje. S druge strane, duševno zdravlje ne uključuje uvijek sreću, već često i patnju, ali ni duševni poremećaj ne uključuje uvijek samo patnju. Kada je osjećaj sreće ili nesreće povezan s iskrivljenom percepcijom sebe i realnosti, tada se radi o duševnom poremećaju, i obrnuto, ako doživljaj sreće i nesreće odražava primjerenu percepciju realiteta, radi se o duševno zdravim osobama. Imajući u vidu različite definicije koje se mogu naći u literaturi, može se reći da duševno zdravlje uključuje određene vještine, karakteristike i ponašanja kao što su: 1. sposobnost da se živi produktivan i ispunjen život, 2. sposobnost da se voli, radi i surađuje s drugima, 3. prilagodbu na svijet i skladan odnos sa sobom i drugima, 4. osjećaj zadovoljstva i sreće, 5. mogućnost učenja, osobnog rasta i razvoja, 6. emocionalnu rezilienciju koja omogućuje uživanje u životu i prevladavanje boli, razočaranosti i tuge, 7. duhovnost, 8. osjećaj povjerenja, kompetencije, postignuća, humora itd. Drugim riječima, duševno zdrava osoba ima osjećaj samopoštovanja i poštuje druge, prihvaća svoje i dobre i loše strane, autentično je zainteresirana za druge ljude i solidarna s njima, ima sposobnost samokontrole i povezivanja i udruživanja $\mathrm{s}$ drugim ljudima, ima primjerenu percepciju realiteta i ciljno usmjerenje $u$ životu, prilagođena je svojoj okolini, sposobna je za radost i sreću.

Krajem prošlog stoljeća Rowe \& Kahn (7) promovirali su koncept uspješnog starenja koji je vremenom postao dominirajući pristup u gerontologiji. Medicinskim jezikom kazano, radi se o zdravom starenju u smislu pozitivnog zdravlja, što znači da netko i s kroničnom bolešću može imati kvalitetan i kreativan život.

\section{Uspješno starenje kao cjeloživotni, međugeneracijski proces}

Posljednjih godina prisutna je tendencija da se najpopularniji model uspješnog starenja koji su postavili Rowe \& Kahn $(7,9)$ stalno pokušava usavršiti $(9)$. 
Postoje dvije suprotstavljene polazne pozicije u oblikovanju teorije uspješnog starenja: teorija aktivne starosti (activity theory) i teorija povlačenja ( $d i$ sengament theory). Popularniji je koncept aktivne starosti po kojemu je za osobe starije životne dobi poželjno da nastave s aktivnostima, dok koncept povlačenja polazi od želje osoba starije dobi da se s vremenom povuku iz aktivnog života (1). Treći koncept naglašava važnost prilagodbe na povlačenje i mirovinu i uključuje tri oblika dobre prilagodbe povlačenjem, a to su zrela prilagodba, tip stolice za ljuljanje i oklopljeni tip (armored type). Zreli i oklopljeni tip temelje se na aktivnostima i angažmanima koji su izvor životnog zadovoljstva. S druge strane su dva oblika loše adaptacije i neuspješnog starenja koji se odnose na okrivljavanje drugih za svoje nezadovoljstvo u starosti i samookrivljavanje za svoju nesreću (1).

Tri su kriterija uspješnog starenja: odsustvo (sloboda od) bolesti i dizabiliteta, visoka razina kognitivnog i tjelesnog/fizičkog funkcioniranja i aktivna uključenost u život (1). Što je više kriterija ispunjeno, to je starenje uspješnije. Starenje implicira raznovrsne promjene, kako na mikro ili staničnoj tako i na makro ili organskoj razini, koje se tijekom vremena akumuliraju dovodeći do funkcionalnih oštećenja. Model leće predstavlja način mišljenja o opisivanju odnosa između okoline i ponašanja organizma u širem smislu riječi, odnosno čovjeka u užem smislu, u određenoj okolini. Model je ustanovio Egon Brunswik, a popularizirao ga Kenneth Hammond. Sastoji se od 4 elementa: kriterij (criterion) - procjena (judgement) i smjeranje (cues) - postignuće (achievement), a shema procesa mišljenja podsjeća na svjetlo koje prolazi kroz konveksnu leću.

\section{Starost između očaja i mudrosti: Pet temelja duševnog zdravlja} i uspješnog starenja

Starost može biti razdoblje osobnog ispunjenja, ali i razdoblje velike patnje. Prema Eriku Eriksonu starost je razdoblje osobnog integriteta i životne mudrosti ili pak očaja i nemoći. Mudrost predstavlja integraciju znanja, iskustva i dubokog razumijevanja života, pojava i procesa pa se kaže da svijet ostaje na mladima, ali opstaje na starijima. Paul Baltes (1939-2006), poznati ekspert za razvojnu psihologiju, koji je bio voditelj Berlinskog projekta mudrosti na Max Planck institutu za ljudski razvoj, definirao je mudrost kao stručni sustav znanja koji se tiče fundamentalne pragmatike života. Mudrost se temelji na bogatom proceduralnom znanju o životu, bogatom činjeničnom znanju o životu, razumijevanju različitih životnih okolnosti, svjesnosti o relativnosti 
vrijednosti i prioriteta (ja bih radije rekao o svjesnosti i znanju o pravim životnim vrijednostima) i sposobnosti snalaženja i ovladavanja neizvjesnostima. Tijekom života mudrost se razvija i oblikuje kao osobna crta ili karakteristika kroz refleksivna razmišljanja, suosjećajnost i traženje istine. Mudri ljudi radije gledaju na život, svijet i događanja u njemu iz više različitih perspektiva, kreativno ih integrirajući kroz sistemsko mišljenje, jer crno-bijeli pogled na svijet često stvara iskrivljenu sliku i vodi u sukobe. Kreativna otvorenost za novo uz poštivanje tradicije i umijeće balansiranja između kompetitivnih zahtjeva i ciljeva važne su sastavnice mudrosti. Mudrost uz znanje uključuje i ispravna vjerovanja o pet ključnih pojmova i odrednica uspješnog života, a to su: ljubav, moć, sloboda, smisao i sreća. Pet velikih sastavnica mudrosti i uspješnog starenja očituju se u tri dimenzije: kognitivno-refleksivnoj, afektivnoj i bihevioralnoj. Kognitivno-refleksivna dimenzija uključuje razumijevanje života, težnju za istinom i dubljim shvaćanjem pojava, događaja i procesa kako na intrapersonalnoj tako i na interpersonalnoj razini, odnosno uvid u pravu prirodu stvari i motiva koji pokreću ponašanje i kreiraju odnose. Afektivna dimenzija uključuje prisustvo pozitivnih emocija, suosjećajnost, simpatiju i empatiju, odnosno odsustvo negativnih emocija. Bihevioralna se dimenzija očituje ponašanjem koje se oblikuje na temelju donošenja odluka pod utjecajem kognitivne i emocionalne sastavnice, odnosno označava komunikacijske vještine i ponašanja koja odražavaju životnu mudrost. Mudre su osobe sretne, miroljubive i moćne/utjecajne, dobro prepoznaju što mogu, a što ne mogu. Poznaju svoje granice, iz patnje uče i duhovno rastu i jačaju. Poznata je molitva: Bože, daj mi smirenost da prihvatim stvari koje ne mogu promijeniti, hrabrost da mijenjam stvari koje mogu promijeniti i mudrost da znam razliku između njih.

Ljubav ima različito značenje za različite ljude, jednima je svetinja, a drugima beznačajna iluzija. Ona je jedna od najvažnijih emocija i psiholoških potreba koja se nalazi u temeljima života i njegova smisla. Ljubav i osjećaj pripadnosti bitno određuju naše zdravlje, naše ponašanje, osjećaj dobrobiti i blagostanja, kvalitetu odnosa s drugim ljudima. U psihologijskom kontekstu ljubav predstavlja kompleksnu i temeljno integriranu emociju koja uključuje jaku privrženost, osjećaj raznježenosti i ugodne senzacije u prisustvu voljenog objekta te posvećenost dobrobiti voljenog objekta. Obično razlikujemo uvjetovanu (recipročni altruizam) i bezuvjetnu ljubav. Uvjetovana ljubav sadrži ograničenja kada, koga i pod kojim uvjetima se može voljeti. Neke osobe vole samo pod određenim uvjetima, a kad ti uvjeti nisu zadovoljeni ili kad prestanu biti poštovani, onda prestaju iskazivati svoju ljubav. Njihova je 
ljubav uvjetovana određenim očekivanjima, interesima i ciljevima. Voljet ću te ako se slažeš sa mnom i zadovoljavaš moje želje i potrebe, ako zaslužiš moju ljubav i povjerenje, ako me staviš na prvo mjesto u svojemu životu, ako mi ne budeš stvarao probleme i neugodnosti, ako mi možeš osigurati bogat i udoban život, ako mi budeš dobar/ra, iskren/a, vjeran/na, lojalan/na, ako me razumiješ, uveseljavaš i činiš radosnom itd. Ideal predstavlja bezuvjetna ljubav koja je prihvaćajuća, tolerantna, kreativna, djelotvorna, obogaćujuća, pomažuća, usrećujuća, fleksibilna, zaštitnička, puna razumijevanja... Prema Erichu Frommu važno je razlikovati "ljubav kao odnos prema određenoj osobi” i osobama (ljubav prema bliskoj osobi), odnosno određenim objektima, i "ljubav kao orijentaciju bića prema svijetu u cjelini” (ljubav prema bližnjemu) (10). Drugim riječima, možemo govoriti o emocionalnoj i duhovnoj razini ljubavi. Na duhovnoj razini ljubav ne očekuje i ne zahtijeva ništa zauzvrat jer je ona sama po sebi svoj razlog postojanja i zato je slobodna. Prema nekim mišljenjima, ako volimo samo na emocionalnoj razini, onda uvijek očekujemo nešto zauzvrat pa se radi o uvjetovanoj ljubavi, pri čemu smo robovi svojih emocija. Duhovnost nam omogućuje veću slobodu izbora tako da ne moramo biti lutke na koncu naših emocija i statisti u sklopu neke sapunice, plitke komedije ili duboke tragedije. Nedostatak ljubavi, koji se često očituje i kroz uvjetovanost ljubavi i razne oblike pseudoljubavi, može izravno ili posredno pridonijeti razvoju otuđenosti i većine duševnih poremećaja, ali mnogih psihosomatskih bolesti. Naime, nedostatak ili gubitak ljubavi ne ostavlja samo negativne psihološke posljedice nego dovodi i do neurobioloških promjena koje za sobom povlače pojavu duševnih smetnji i poremećaja.

Ljubav nije samo ideja ili predodžba pojedinca o tomu što ona jeste, ona je stanje mozga, ali i cijelog tijela, povezano s aktivnošću određenih neuronalnih mreža i u njima aktivnih neurotransmitora, neuropeptida i hormona. Različite strukture mozga igraju značajnu ulogu u generiranju ljubavi, a najvažnije su: amigdaloidna jezgra, prefrontalni korteks, prednji cingularni korteks, ventralni strijatum i insularni korteks. Dovoljno ljubavi u ranom djetinjstvu stimulira oslobađanje dopamina koji nas potiče na borbenost, kreativnost, postizanje svojih ciljeva, podiže samopouzdanje i snagu za život. Kada se dopamin ne luči dovoljno, u frontalnom korteksu dolazi do mentalne dezorganizacije, slabije koncentracije, emocionalne labilnosti, anksioznosti i panike. Skeniranje mozgova ljudi koji gledaju fotografije osoba koje vole pokazalo je povećanje aktivnosti dopamina. No, treba imati na umu da dopamin može izvući i najbolje i najgore iz ljudi. Istraživanja pokazuju kako je razina serotonina 
u odrasloj dobi niža ako nije bilo dovoljno ljubavi u djetinjstvu, a sindrom niskog serotonina može se očitovati kroz raznovrsne anksiozne i depresivne poremećaje, poremećaje kontrole poriva, agresivno ponašanje i sklonost zlouporabi alkohola. Nadalje, djeca koja su odgajana bez majki i bez dovoljno nježnosti, dodira i zagrljaja imaju visoku razinu hormona stresa, npr. ACTH i kortizola, a disfunkcija hipotalamično-hipofizno-adrenalne osi opisana je ne samo u depresivnim nego i drugim poremećajima.

Opraštanje je tijesno povezano s ljubavlju jer samo ljubav može istinski oprostiti, a to mogu prakticirati samo duhovno visokorazvijene osobe. Za mnoge je to nažalost psihološki neprirodno stanje o kojemu se može lijepo pričati, ali ga je teško prakticirati. Opraštanje se uglavnom doživljava kao teološki konstrukt prisutan u svim velikim religijama i važna je sastavnica duhovnog zdravlja. Međutim, mnogi ljudi misle da je opraštanje neprirodno te da nam osjećaj za pravdu govori da ljudi moraju ispaštati za zlo koje čine. Prema Monbourquetteu (1997) osveta je na neki način instinktivna pravednost koja dolazi od primitivnih bogova podsvijesti i predstavlja najspontaniju i najinstinktivniju reakciju na uvredu ili povredu. Pribavlja osvetniku narcisoidni užitak stavljajući kratkotrajni melem na njegovu osobnu patnju i poniženje. Međutim, opraštanje je duhovna snaga koja nadvladava instinktivnu reakciju i prirodno pravilo. Opraštanje je novo duhovno viđenje i novi duhovni osjećaj koji obdaruje osobu koja prašta. Samo hrabri mogu opraštati. Prema nekim mišljenjima opraštanje je važna sastavnica duhovne inteligencije. Opraštanje nam omogućuje da živimo u vedrom i mirnom stanju duha, a na svoj paradoksalan i neuhvatljiv način otvara vrata i mnogim drugim duhovnim darovima. Opraštanje može biti i svjesni životni izbor da se usredotočavamo na dobrobit i blagodati života umjesto da živimo u prošlosti, mržnji i drugim negativnim emocijama. Tako je opraštanje zapravo duhovna praksa pozitivnog pristupa životu u ljubavi. To je zapravo proces koji pretvara patnju, ljutnju i bijes u više vibracijske frekvencije ljubavi. Stoga opraštanje može biti snažno terapijsko sredstvo. Prema Desmondu Tutu, južnoafričkom nadbiskupu i dobitniku Nobelove nagrade za mir, "opraštanje je način da sačuvamo zajednicu od raspada”.

Jedna od najvećih zapreka doživljavanju punoće i radosti življenja jest u nezahvalnosti. Često zbog ludog tempa života nemamo vremena za tišinu i razmišljanje o blagoslovima života. Kvaliteta našega života ovisi o onome na što usmjeravamo svoju pozornost i svoje misli. Duhovno zdrava osoba je blagoslovljena zato što može sa zahvalnošću učiti, rasti, voljeti, opraštati, stvarati, dijeliti i pomagati drugima. Znati zahvaljivati znači znati se usmjeravati na 
ono što je dobro u životu, a mjera je i duhovnog i duševnog zdravlja sklonost pronalaženju dobra u sebi i oko sebe. Psiholozi su razvili različite metode za učenje zahvalnosti. Prema metodi u četiri koraka: 1. prvo treba prepoznati svoje negativne i nezahvalne misli, zatim 2. oblikovati pozitivne i zahvalne misli, potom 3. zamijeniti nezahvalne zahvalnim mislima, i na kraju 4. pretvoriti pozitivne i zahvalne misli i osjećaje zahvalnosti u ponašanje $i$ vanjsko djelovanje. Pisanje dnevnika zahvalnosti vrlo je djelotvorna metoda prakticiranja zahvalnosti kao životnog stila. Zahvalnost je duhovni stav i način postojanja koji iscjeljuje i dušu i tijelo. Zahvalna razmatranja i dnevnik zahvalnosti mogu značajno poboljšati kvalitetu našega života i zdravlja. Zahvalnost i zahvaljivanje uzdižu nas na višu razinu svijesti koja je povezana s boljim životom. "Hvala Ti, Bože, za svu dobrotu i darove" je iskaz koji, kad se ponavlja, na čudesne načine može aktivirati kreativne potencijale i snagu. Kad smo zahvalni za ono što imamo, zahvalnost za život, njegove lekcije i darove umnožava dobro u našim životima. Istraživanja pokazuju da zahvalni ljudi lakše dobivaju podršku drugih ljudi, bolje se snalaze u životu, zdraviji su i društveno prilagodljiviji. Prema Robertu A. Emmonsu i Joanni Hill "budite zahvalni i doživjet ćete radost, sreću i ispunjenost”. Ljudi koji su svjesni božanske prisutnosti, češće i dulje se dive ljepoti koja ih okružuje i svjesniji su dobrote i darova koji im se nude.

Smisao života je usko povezan s pitanjem životnog poslanja i poziva. Životna zadaća svake osobe je jedinstvena i samo je ta osoba može ostvariti, a naš je najveći izazov uspješno ostvarenje našega autentičnog životnog poslanja. Poslanje (lat. missio od misus, što znači "poslan") označava naš unutarnji spiritualni program ili životni skript. Životni poziv (lat. vocatus što znači "biti pozvan") je zov koji dolazi iz dubine naše duše, a životna vizija (lat. visio od visus što znači "koji je viđen") je unutarnja slika životnog plana. Na našem životnom putovanju postoje 4 nezaobilazna puta, kako to kaže Jorge Bucay, psihijatar, psihoterapeut i pisac svjetski poznatih bestselera, a to su: 1. put konačnog susreta sa samim sobom, koji naziva putem samoovisnosti, a ja bih dodao i putem samoostvarenja i samoaktualizacije, 2. put susreta s drugim, put ljubavi i putenosti, koji naziva putem susreta; 3. put gubitaka i žalosti, koji naziva putem suza; i 4. put ispunjenosti i traženja smisla, koji naziva putem sreće. Kako prepoznati osobno poslanje, ispravno odgovoriti na unutarnji zov, kako ispravno vidjeti i slijediti svoju pravu životnu viziju važna su egzistencijalna, sudbinska pitanja. Svatko mora sam otkriti svoje poslanje, koje istodobno i privlači i plaši. Poslanje sadrži autentični smisao života i izvor je duhovnog rasta i razvoja. Pitanje "kako prepoznati svoju životnu 
misiju" tijesno je povezano s osjećajem pripadnosti, a osjećaj pripadnosti povezan je s našim ulogama u zajednicama kojima pripadamo. Može se prepoznati u idealima koje slijedimo, u strastima i snažnom zanosu prema nekim aktivnostima, u dugotrajnoj i potpunoj predanosti nekim ciljevima... Naime, osim što pripadamo obitelji, mi pripadamo i različitim kulturnim, duhovnim, političkim, ekonomskim, profesionalnim zajednicama u kojima imamo i igramo različite uloge. Obično razlikujemo individualne ili osobne uloge, koje su temelj za sve druge uloge: obiteljske (uloga roditelja, sina ili kćeri, brata ili sestre itd.), društvene ili građanske (npr. građanski aktivist, borac za ljudska prava, zaštitnik prirode, dragovoljni davalac krvi, volonter itd.), političke (zastupnik u saboru, predsjednik države, predsjednik stranke, član stranke itd.), profesionalne (npr. uloga liječnika, odvjetnika, studenta, profesora itd., uloga kolege, poslovnog partnera), psihološke uloge (žrtva, progonitelj, spasitelj), seksualne uloge (homoseksualne, biseksualne, heteroseksualne) itd. Poistovjećivanje s pojedinim ulogama iznimno je bitno za oblikovanje naših identiteta, a kako ostvarujemo svoje uloge bitno određuje kvalitetu našega života i zdravlja, a sam tim i starenja.

Sreća je pojam o kojemu svi govore, svi se slažu da svatko želi biti sretan, odnosno da nitko ne želi biti nesretan, ali je ipak mnogi ne osjećaju često ili je ne prepoznaju dugotrajno u svom životu. Prema Dalaj Lami (1995) svrha ili smisao života je biti sretan. Čini se kako je ideologija sreće i pozitivnog mišljenja toliko hipertrofirala kao vulgarni i egoistični epikureizam da se pretvorila u kult i pravu tiraniju. Tiranija sreće nije preplavila samo popularnu već i profesionalnu kulturu. Naša kultura je prezasićena očekivanjima da mislimo pozitivno, da trebamo i moramo biti optimisti s pozitivnim emocijama i gledištima te da se moramo maksimalno posvetiti ostvarivanju sreće, zdravlja i mudrosti, najčešće vrlo površne mudrosti koja to zapravo i nije. Evidentno je da je tiranija sreće povezana s tiranijom glagola trebati i morati. Potraga za srećom na neki način postala je diktat, a njezino ispunjenje mjeri se primarno vanjskim mjerilima (bogatstvo, moć, slava, ljepota itd.). Recepti za sreću i uspjeh posvuda se nude i preporučaju. Od optimizma i pozitivnog mišljenja, tvrdi se, nema boljeg lijeka za sve životne nevolje, zlu kob, lošu hudu sudbinu te za povoljan ishod bolesti... Po Martinu Seligmanu optimizam i sreća do koje on dovodi mogu se naučiti. Ako se netko ne može izdići iznad nevolje, patnje ili bolesti, onda je sam kriv, jer ne misli pozitivno i ne zna biti sretan. Koncept sreće tako je pretvoren u imperative postizanja sreće, u neku vrstu kulta sreće. Ovakva despotska sreća, po nekim mišljenjima, dovodi do sve većeg broja nesretnih ljudi koji osjećaju i krivnju zato što nisu sretni. Osjećaj 
krivnje samo još više produbljuje patnju i tako se uspostavlja začarani krug, circulus viciosus. Za kritičare koncepta sreće u prirodi ljudskog života nije da bude sretan te oni smatraju da je sretan život u stvari falsifikat sretnog života. Prema Hegelu povijest svijeta nije povijest sreće, a za Schopenhauera život je pun boli i dosade. Nadalje, sretan život ne pogoduje stvaralaštvu niti dovodi do otkrivanja pravih istina o svijetu i nama ljudima kao što omogućuje tragično osjećanje života i moć negativnog mišljenja. Prema Aristotelu sreća (eudaimonia - "biti u naklonosti bogova") je čovjeku dostižna kroz dobro, krjeposno i pravedno življenje (eupraxia) i u zajedništvu (polis), a uvjet za dostignuće sreće je mudrost (sophia). Prema svetom Augustinu blaženost čovjek ne postiže kroz težnju dobrima ovoga svijeta, nego samo po Bogu i u Bogu. Prema Tomi Akvinskom čovjek sreću postiže dobrim djelima. Za filozofe renesanse sreća je duhovno zadovoljstvo i harmonija duše koja se dostiže moralnim djelovanjem, pri čemu individualno valja podrediti dobrobiti cjeline. Po mišljenju mnogih filozofa svaka samo individualna sreća je nedostatna, zapravo pogrešna. S obzirom na to da je duhovnost ta koja nas povezuje s nečim većim i uzvišenim, logično je da je prava sreća ona koju gradimo i dijelimo s drugima. Sreća nije samo u tomu da možemo raditi samo ono što volimo, već da volimo ono što radimo i da to radimo za one koje volimo i s onima koje volimo. Važno je imati na umu kako u životu sve dobiva na vrijednosti kroz svoju suprotnost tako da "svaka radost ima svoju tugu, a svaka tuga ima svoju radost". Pitanje sreće je zapravo pitanje smisla života i ostvarenja svojih autentičnih potencijala. Živjeti ljudski život znači iskusiti i radost i tugu, biti ushićen i deprimiran, oduševljen i razočaran, pa i očajan. Izmjenjivanje ovakvih stanja daje čar životu. U životu sve dobiva na vrijednosti kroz svoju suprotnost. Svaka radost ima svoju tugu, i svaka tuga ima svoju radost. Prema Adornu sreća je posredovana patnjom. Duhovnost nam omogućuje da transcendiramo patnju i preobrazimo je u sreću. Ne postoji lagani put ili prečica do sretnog života. Sreće je povezana s umijećem (ars vivendi) i smislom življenja, pri čemu je ona zasigurno mnogo veća ako je možemo dijeliti s drugima. Razmišljati o sreći zapravo znači razmišljati o ljubavi, smislu, vrijednostima i krepostima. Za dobar i sretan život važna je životna mudrost, a ona je povezana s duhovnom inteligencijom koja nam omogućuje prepoznavanje pravog smisla i svrhe življenja. Biti sretan ne znači naći sreću ili imati sreću, ona se događa u nama kao aktivna ljubav i dobrota koju biramo i prakticiramo. Sreća nije nešto što se stječe, ona je umijeće koje valja stalno usavršavati kroz čarobne dodire i blagoslovljene susrete. Ono što sijemo, to ćemo požnjeti. Antony de Mello kaže da svaki čovjek u sebi ima 
sve ono što mu je potrebno da bude sretan. Ljubav je naš izbor. "Oni među vama koji će biti istinski sretni su oni koji traže i otkriju kako pomagati." (Albert Schweitzer).

\section{Model leće: reziliencija, epigenetika i komorbiditet određuju uspješno starenje}

Postoje brojni modeli uspješnog starenja, pri čemu mnogi uključuju sljedeće teme: 1. uspješno starenje je dugotrajan cjeloživotni proces; 2 . uspješno starenje uključuje mnoge domene, nije isključivo ograničeno na zdravlje, nego je u širem smislu povezano s biološkom, psihološkom, socijalnom i duhovnom dimenzijom ljudske egzistencije; 3. uspješno starenje je određeno vrstom i kvalitetom odgovora na izazove; 4. uspješno starenje se definira strogo individualno za svaku osobu ovisno o njenim individualnim ciljevima i preferencijama; 5. sposobnost za uspješno starenje je djelomično pod kontrolom svake osobe, primjerice kroz nova učenja, a dijelom je predodređeno, primjerice genetski (11). Prema modelu leće brojni personalni čimbenici, npr. personalni resursi i pogled na život, uz okolinske čimbenike, ulaze u interakciju kreirajući leću kroz koju neka osoba doživljava izazove i prilagođava im se: iskustva s nedaćama, socijalna podrška, nada, osjećaj osobne vrijednosti, osjećaj za humor, samoodređenje, suportivna fizička okolina, financijski status i samoučinkovitost (11).

Reziliencija predstavlja složeni skup raznovrsnih protektivnih i salutogenih čimbenika i procesa vrlo bitnih za razumijevanje zdravlja i bolesti, procesa liječenja i iscjeljenja pa time i uspješnog starenja. Radi se o biološkim, psihološkim, socijalnim i spiritualnim čimbenicima i mehanizmima koji u svakoj životnoj dobi moduliraju odnos između stresa, traume i/ili bolesti s jedne strane i pozitivnog, povoljnog ili poželjnog ishoda s druge strane (12). U kontekstu uspješnog starenja važno je imati na umu da postoje različiti oblici reziliencije te da u skladu s kaskadnim modelom pojedini čimbenici reziliencije mogu pridonijeti razvoju drugih. U našem kontekstu korisno je imati u vidu osobnu i grupnu rezilienciju $(13,14)$, fiziološku, psihološku, socijalnu i duhovnu rezilienciju $(15,16)$, te primarnu, sekundarnu i tercijarnu rezilienciju (17). Psihološka i duhovna reziliencija zapravo predstavljaju psihološke i duhovne mehanizme obrane u kriznim stanjima, stanjima stresa i traume. Psihološka i duhovna reziliencija, koje uključuju nadu, djelovanje (agency), svrhu i smisao, zajedništvo, zahvalnost i radost, nadvladavaju vulnerabilnost, koja uključuje očaj, bespomoćnost, besmislenost, izolaciju, 
ljutnju i tugu. Primarna reziliencija je povezana s održavanjem balansa, ekvilibrija i zdravlja, čime se osigurava blagostanje i preveniraju sa stresom povezane bolesti. Sekundarna reziliencija označava čimbenike i procese koji nam omogućuju da se uspješno nosimo s krizama i bolestima i da ponovo uspostavimo zdravlje i psihosomatski sklad. Tercijarna reziliencija predstavlja sposobnost neke osobe da živi zadovoljno, kreativno i produktivno unatoč prisustvu jedne ili više kroničnih bolesti, odnosno da se u starijoj životnoj dobi osoba aktivno i pozitivno prilagodi objektivnim ograničenjima. Iz navedenog proizlazi da primarna reziliencija omogućuje dobro zdravlje, tjelesno, psihološko, socijalno i duhovno blagostanje, sekundarno izlječenje i personalni oporavak, a tercijarna kvalitetan život i osjećaj dobrobiti unatoč kroničnoj bolesti. Primjerena reziliencija je preduvjet za uspješno starenje. Svaki čovjek je jedinstvena, responsivna i odgovorna osoba koja teži samoostvarenju (samorealizaciji), samorazumijevanju i samotranscendenciji te vlastitom integritetu, samokontroli i upravljanju svojim životom. Dobra je vijest da se reziliencija može povećavati i održavati učenjem i treningom.

Epigenetika nam objašnjava kako mi često nismo žrtva naših gena, već da i naši geni mogu biti žrtva našega životnog stila i ponašanja. Epigenetski mehanizmi regulacije genske ekspresije imaju važnu ulogu u procesima starenja, rezilienciji, nastanku raznih bolesti, te komorbidnih i multimorbidnih stanja (18). Epigenom predstavlja molekulsku memoriju obrasca aktivnosti koji se prenosi na stanice kćeri, a epigenetsko nasljeđivanje odnosi se na transmisiju i očuvanje informacija kroz mejozu ili mitozu, a ne utemeljeno na sekvenci nukleotida. Epigenetski procesi su povezani s različitim razinama genske ekspresije, od izravne modifikacije DNA i histona koja regulira razinu transkripcije do interakcija s mRNA i regulacijom razine translacije. Starenje je povezano s bitnim promjenama epigenetskih mehanizama, a bolesti koje se javljaju sa starenjem organizma, kao što su dijabetes, koronarna bolest, depresija, Parkinsonova bolest, demencija itd., mogu biti posljedica promjena $\mathrm{u}$ epigenetskim regulatornim procesima. Epigenetski sat je pokazatelj istinske biološke dobi tkiva, pri čemu je medijan greške odstupanja manji od 5 godina. Epigenetska regulacija je iznimno važna u različitim neuralnim procesima kao što mitohondrijske funkcije, stvaranje (folding) proteina u endoplazmatskom retikulumu, nuklearnim procesima koji reguliraju duljinu telomera, oporavaka DNA. Epigenetski mehanizmi uključeni su i u procese neurogeneze, reziliencije, neuroplastičnosti, pamćenja i učenja (19). Treba uvijek imati na umu da epigenetske promjene mogu biti povezane, osim sa starenjem, i sa utjecajima okoline, životnog stila i aktualnog stanja neke sobe. Obično 
razlikujemo tri temeljna epigenetska mehanizma, a to su DNA metilacija, modifikacija histona i disregulacija mikroRNA, s tim da ima najviše podataka o DNA metilaciji i starenju. Radi se o vezivanju metilne skupine na poziciju 5 pirimidinskog prstena citozina pa nastaje 5-metilcitozin (5.mC). Ovo se događa primarno, ali ne i isključivo na $\mathrm{CpG}$ (citozin-fosfat-guanin) otočićima $\mathrm{S}$ dobi povezane promjene DNA metilacije mogu se očitovati kao epigenetski drift (naplavina) i epigenetski fenomen sata. Epigenetski drift predstavlja globalne promjene DNA metilacije uzrokovane slučajnim i okolinski individualno specifičnim čimbenicima, a epigenetski sat predstavlja progresivne epigenetske promjene povezane sa starenjem na specifičnim mjestima u genomu koje su česte među individuama i nalaze se u različitim tipovima tkiva. Drugim riječima, epigenetski drift predstavlja tendenciju povećanja nesklada između epigenoma tijekom vremena, a epigenetski sat opisuje sličnosti u svezi sa životnom dobi. S povećanjem životne dobi dolazi do globalnog smanjenja DNA metilacije, pri čemu mogu postojati značajne razlike između različitih tkiva, a vrsta promjena ovisi o tipu tkiva. Opisana je smanjena razina aktivnosti nuklearne DNMT1 (DNA-metiltransferaze 1) postmortalno u mozgu bolesnika s Parkinsonovom bolešću i Lewy body demencijom. Kako je starenje primarni čimbenik rizika za mnoge neurodegenerativne bolesti, multimorbiditete, komorbiditete i sindemije, logično je za očekivati važnu ulogu epigenetskih mehanizama.

U starijoj životnoj dobi komorbiditet i multimorbiditet, odnosno istovremena pojava različitih patoloških stanja i bolesti, više su pravilo nego izuzetak (20). Prema nekim mišljenjima termin multimorbiditet označava istovremenu pojavu dvije ili više somatske bolesti i/ili duševna poremećaja, pri čemu nijedna bolest ili poremećaj nisu predominantni, dok komorbiditet predstavlja pojavu dva ili više patoloških stanja kada je jedno patološko stanje predominantno (21). Sindemija predstavlja istovremeno ili sekvencijalno prisustvo dva ili više patoloških stanja između kojih postoji patofiziološka povezanost, što pogoršava prognozu i smanjuje kvalitetu, a katkada i trajanje života (22). Većina duševnih poremećaja češće se javlja u somatskih bolesnika u usporedbi s općom populacijom, i obrnuto, učestalost tjelesnih bolesti je značajno veća u osoba s psihijatrijskim poremećajima. Psihijatri često ne prepoznaju na vrijeme tjelesne bolesti u svojih bolesnika, kao što ni liječnici u drugim granama medicine često ne prepoznaju psihičke poremećaje kod svojih bolesnika, a što se negativno odražava na rezultat liječenja i kvalitetu života u osoba starije životne dobi. 


\section{Uspješno starenje: promocija neuroreziliencije i zdravlja mozga}

Uspješno starenje uključuje aktivnosti ne samo na osobnoj i obiteljskoj već i na društvenoj i političkoj razini. Opadanje sposobnosti i slabije funkcioniranje, krhkost, umiranje i smrt su normalne sastavnice završne faze življenja (conditio humana), zbog čega uspješno starenje treba promatrati i kroz leće ne samo zdravog starenja već i dizabiliteta. Iz svega gore navedenog razvidno je da uspješno starenje ovisi o cijelom nisu različitih procesa kako na molekularnoj, staničnoj i organskoj tako i na personalnoj i interpersonalnoj razini, odnosnoj psihološkoj, socijalnoj i spiritualnoj razni. Drugim riječima, uspješno starenje ovisi o fiziološkoj, psihološkoj, socijalnoj i duhovnoj rezilienciji. Neuroreziliencija se pospješuje prehranom zdravom za mozak i mentalnim vježbama za mozak, dakle povezana je sa zdravljem mozga i na neki način sinkronizira fiziološku, psihološku, socijalnu i duhovnu rezilienciju. Zdravom prehranom i ljekovitim dodacima prehrani, kao što su antioksidansi, probiotici, vitamini, glukozamin, ginkgo, acetil-1-karnitin, silimarin itd. te različitim tjelesnim, ili bolje reći psihofizičkim aktivnostima, kao što su ples, gimnastika, tai-chi itd., može se pojačati fiziološka rezistencija, smanjiti upalni procesi, usporiti neuro/degenerativne promjene, povoljno djelovati na kardiovaskularni sustav. Potvrđeno je da su fizičke aktivnosti i vježbe praćene povećanjem razine protuupalnih citokina i smanjenjem razine upalnih citokina (15).

Intervencije koje promoviraju psihološku rezilienciju i uspješno starenje usmjerene su na oblikovanje pet temelja duševnog zdravlja: ljubav, moć, sreću, slobodu i smisao (vidjeti tab. 4), kao i na jačanje i oblikovanje karakternih crta: samokontrola i upravljanje sobom (self-directedness), suradljivost (cooperativeness) i samotranscendencija (self-transcendence).

Tablica 2. Jačanje karaktera, promocija reziliencije i uspješno starenje

\begin{tabular}{ll}
\hline $\begin{array}{l}\text { Proaktivnost i upravljanje } \\
\text { sobom (self-directedness) }\end{array}$ & $\begin{array}{l}\text { Poticanje zdravih stilova življenja, fizičke aktivnosti i čvrstine, optimizma, pozitivne } \\
\text { afektivnosti, pozitivnog mišljenja i pozitivnih kognitivnih procjena i afilijativnog } \\
\text { ponašanja }\end{array}$ \\
\hline Suradljivost (cooperativeness) & $\begin{array}{l}\text { Poticanje pozitivnih zajedničkih interakcija sa suportivnom okolinom } \\
\text { (podrška profesionalnih pomagača, npr. liječnika), članova obitelji, } \\
\text { prijatelja }\end{array}$ \\
\hline $\begin{array}{l}\text { Samotranscendencija } \\
\text { (self-transcendence) }\end{array}$ & Duhovno povezivanje s uzvišenim i svetim \\
\hline
\end{tabular}


Psihološka rezistencija je povezana s više prakticiranja ljubavi i mudrosti i vježbanjem sreće u svakodnevnom životu, raditi ono što volimo i voljeti ono što radimo za ljude koje volimo i s ljudima koje volimo.

Socijalna reziliencija je povezana sa socijalnim kapitalom i socijalnom podrškom. Starenje je praćeno velikim izazovima i neizbježnim gubicima, primjerice zdravlja, financijske sigurnosti, funkcionalnih sposobnosti, društvenih i poslovnih uloga, odnosa. Neki od razvojnih zadataka u starosti odnose se na prilagodbu na značajne životne promjene kao što su umirovljenje, promjena socijalnog statusa, napuštanje određenih društvenih uloga, smrt članova obitelji i prijatelja. Poznata je činjenica kako sindrom statusa bitno određuje naše zdravlje, duljinu života i uspješno starenje (23). Održavanjem i obogaćivanjem društvenih aktivnosti i kontakata značajno se pridonosi uspješnom starenju.

Spiritualna reziliencija je povezana s duhovnošću. Čovjek po svojoj naravi čezne za nečim vrijednim, dobrim, lijepim, uzvišenim, pa i nadnaravnim, a duhovnost označava sposobnost uspostavljanja veze sa svojim istinskim bićem, s božanskim u sebi, kao i prepoznavanje istinski životnih vrijednosti, svrhe i ciljeva. U ovom kontekstu duhovnost je povezana s čovjekovom sposobnošću stvaranja i prihvaćanja ideja koje motiviraju i usmjeravaju njegovo doživljavanje, ponašanje i život u cjelini. Drugim riječima, radi se o traganju za značenjem, vrijednostima i smislom života, a samim tim i zdravlja i bolesti, dobra i zla, te istinskom srećom i blagostanjem kroz sposobnost transcendencije, imaginacije, osmišljavanja i povezivanja s nečim većim, moćnijim i mudrijim od nas samih. Između ostalog, biti duhovan znači biti u dodiru s cjelinom, imati osjećaj sebe u širem, bogatijem i smislenijem kontekstu života, a duhovna inteligencija je inteligencija duše koja nam pomaže prepoznati i kreirati pravi, autentični smisao života. Ako duhovnost predstavlja transcendentnu sposobnost i mogućnost čovjeka da sudjeluje u onome što se nalazi iznad njega samoga i njegova neposrednog i sebičnog interesa, onda duhovno zdravlje znači mogućnost da izađemo iz sebe samih, da stupimo u ispravan odnos s drugima i okolinom te da komuniciramo na kreativan način. Duhovno zdravlje uključuje prisutnost istinske ljubavi, opraštanja, zahvalnosti, velikodušnosti, altruizma, mira i miroljubivosti. Za kršćane to je proces rasta i razvoja u ljubavi i sudjelovanje u božanskoj naravi. 
Nekoliko primjera tehnika koje jačaju rezilienciju

U aktivnosti koje mogu izrazito pozitivno utjecati na zdravlje i kvalitetu života starijih osoba ubrajaju se različite kreativne i umjetničke aktivnosti kao što su slušanje glazbe, sviranje i pjevanje, ples, slikanje itd. Ples u životu ljudi ima vrlo važne funkcije, a u antropološkom i ontološkom smislu izražava se kao iskonska potreba. Plesne aktivnosti potiču vitalnost, održavanje kondicije, pozitivno utječu na kosti i smanjuju rizik od osteoporoze, pozitivno djeluju na mišićnu masu i snagu, na održavanje motoričkih i mentalnih sposobnosti, poboljšavaju spavanje, pridonose boljem raspoloženju, jačaju povezanost $i$ druženje s vršnjacima, potiču društvenost, omogućuju socijalnu podršku okoline, povećavaju životno zadovoljstvo i samopouzdanje (24)... Tjelesna kondicija poboljšava pokretljivost, mobilnost i slobodu kretanja, mogućnost brige o sebi, neovisnost, samostalnost. Usredotočenost na plesne pokrete uz prepuštanje glazbi omogućuje odmak od tmurne svakodnevice i problema koje nosi sa sobom. Zbog svog jakog emocionalnog i socijalnog učinka ples i glazba nalaze primjenu i u terapiji jer potiču resetiranje mozga i pozitivne kognitivne, emocionalne i bihevioralne promjene.

Vježbanje tehnike 101 smiješak dnevno ima povoljan učinak na funkcioniranje mozga i naše raspoloženje i način kako razmišljamo jer je povezano s pozitivnom porukom, a isto tako i na socijalnu komunikaciju s okolinom. Istraživanja su pokazala da, kad se smiješimo, dolazi do oslobađanja dopamina i serotonina. Neki bračni parovi koji su svaki dan ujutro provedu 60 sekundi smiješeći se jedno drugom potvrdili su povoljne psihološke učinke koji mogu značajno pridonositi uspješnijem starenju.

Ples pet ritmova Gabrielle Roth (1941-2012) je metoda koja se sastoji od 5 različitih plesova koji iscjeljuju rascjep između tijela i duše, uma i srca jer njeguju slobodu pokreta, individualnost osobe, promoviraju ljepotu različitosti, promiču prihvaćanje vlastitog tijela. Ova metoda polazi od suštinske potrebe čovjeka da se kreće, da bude pokrenut i da bude u pokretu, da se skladno i blisko povezuje s drugim ljudima i bićima, da se osjeća vitalno, vibrirajuće, spreman da odgovori na životne izazove i uspješno se nosi sa svime što mu život donosi. Plesni ritmovi su grupirani prema pet prirodnih obrazaca kretanja, a svaki ritam predstavlja različito energetsko polje u kojemu plesač nalazi vlastitu ekspresiju i koreografiju. U svakom ritmu plesač plesač otkriva neku specifičnu dimenziju sebe. Tečni (flowing) ritam je fluidan i neprekidan, to je ženski ritam, otvaranja svojoj energiji i autentičnim mogućnostima, plesač se kreće kroz kontinuum kružnih pokreta bez kraja i početka. Staccato ritam, 
udarni i određeni, muški ritam, odvija se u pokretima koji čine kutove. Kaos je divlji i ekstatičan ritam, iz kaosa se rađa novi svijet, plesač doživljava iskustvo svoje cjelovitosti, slobode, intuitivnosti i kreativnosti. Lakoća i igra su odlike lirskog ritma kroz koji plesač uspostavlja kontakt sa svojom jedinstvenošću i ljudskošću, sa svojim obrascima i ciklusima. Na kraju kao eho dolazi smirujući ritam označen kao duboka tišina, mirna praznina kada plesač ulazi i izlazi iz pokreta u tišini, umijeće poniznosti, mudrosti i svjesnosti (mindfulness). Ples pet ritmova nudi razumijevanje čovjeku prirođenih emocija: strah, bijes, tuga, radost i suosjećanje, životnih faza: rođenje, djetinjstvo, pubertet, zrelost i smrt; moći: bivstvovanje, voljenje, spoznavanje, gledanje i iscjeljivanje. Ples "pet ritmova" je metoda koja je pristupačna svima bez obzira na dob i spol, plesno iskustvo ili sposobnosti plesača jer se temelji na improvizaciji. Plesač treba naći svoj ples i ritam i tako pronaći sebe na najvišoj razini fluidnosti i kreativnosti. (25)

Tablica 3. Ples "pet ritmova”

\begin{tabular}{llll}
\hline Tekući ritam & Strah & Bivstovanje & Tijelo \\
\hline Staccato ritam & Bijes/ljutnja & Voljenje & Srce \\
\hline Kaos ritam & Tuga & Spoznavanje & Um \\
\hline Lirski ritam & Radost & Gledanje & Duša \\
\hline Duboka tišina & Suosjećanje & Iscjeljivanje & Duh \\
\hline
\end{tabular}

Trening reziliencije pojačava neuroplastičnost mozga i poboljšava sklad neuralnih krugova koji moduliraju aktivnost moždanih sustava nagrade i kazne, odgovara na stres i procjene opasnosti, emocionalne regulacije i motivacije, adaptivnog socijalnog ponašanja, samousmjeravanja i suradljivosti itd. SWOT (strength, weakness, opportunties, threats) ili hrvatski SSPP (snaga, slabosti, prilike, prijetnje) trening reziliencije uključuje pet stadija: 1. procjena snaga, slabosti, prilika i prijetnji; 2. rekonstrukcija narativa sadašnje nepovoljne ili ograničavajuće situacije ili bolesti i njezina liječenja; 3. kreiranje modela osobne i obiteljske reziliencije; 4. vježbanje specifičnih kognitivno-emocionalno-bihevioralnih tehnika i metoda; i 5. prakticiranje u realnom životu. Vježbanje specifičnih kognitivno-emocionalno-bihevioralnih metoda usmjereno je na optimalno oblikovanje 5 temelja duševnog zdravlja i uspješnog starenja (tab. 4, vježbe 1 i 2) 
Tablica 4. Pet temelja duševnog zdravlja i psihološke i duhovne reziliencije

\begin{tabular}{ll}
\hline Ljubav & privrženost/odanost, povezivanje, pripadanje \\
\hline Sloboda & izbor, neovisnost, autonomija \\
\hline Moć & učenje, postignuća, kontrola \\
\hline Sreća & zabava, igra, zadovoljstvo, uživanje \\
\hline Smisao & značenje, svrha, poslanje i poziv \\
\hline
\end{tabular}

Mala vježba o sreći i smislu

Udobno se smjestite... Sklopite oči... Udahnite duboko i izdahnite polako nekoliko puta... Neka se vaše tijelo, um i emocije umire... Zamislite neko mirno jezero... ili rijeku koja mirno teče... Zamislite potpuni mir...

Kad budete spremni, počnite razmišljati o značenju pojmova sreća i smisao života... Neka vaš um bude otvoren za sve njihove aspekte i značenja... Razmislite o svojemu iskustvu sreće i svrhe života... Što vas čini sretnim/om? Što vam pruža radost? Kako često doživljavate trenutke istinske sreće? Kako znate kad ste sretni? Kakav osjećaj u vama prati pomisao na sreću i smisao života ?... Promatrajte ih iz različitih kutova... Možda vam unutarnji glas nešto govori... ili se možda pojavila neka slika pred vašim unutarnjim očima... Što sreća i smisao života vama znače?... Sjetite se nekih vrhunskih iskustava iz vašega života... Sjetite se nečega što je u vama izazivalo ponos... Kako vam izgleda vaša sreća danas... kako bi mogla izgledati u budućnosti?... Za što vrijedi živjeti?... Imate li snove? Kako sebe možete najbolje ostvariti? Kako možete na najbolji mogući način zaokružiti svoje životno putovanje jednog dana. Pomislite na ono što je u vama jedinstveno... Po čemu se razlikujete od drugih... Što vas čini jedinstvenim/om... Bez vas bi ovaj svijet bio sigurno siromašniji... Dajite uvijek nabolje od sebe.

Kad poželite otvoriti oči, sjetite se da u sebi uvijek možete potražiti i probuditi radost i sreću koju ste nekad doživjeli ... Sjetiti se izreke "jako je malo potrebno da čovjek bude sretan, a još manje da bude nesretan”... Vi uvijek možete izabrati ono prvo... Samo se sjetite nečega što u vama izaziva zahvalnost... vama dragih osoba

\section{Mala vježba o ljubavi}

Udobno se smjestite... Zatvorite oči... Usmjerite svoju pozornost na disanje. Udahnite duboko, malo zadržite dah i polako izdišite. Dok izdišete, osjećate kako se opuštate. Ponovite to nekoliko puta... dok ne postanete posve opušteni. Sjetite se neke rijeke koja mirno teče, bijelih oblaka koji mirno plove 
na plavom nebu, nekog mirnog jezera u kojega utječe rijeka... jeste li nekad razmišljali o rijeci života... ili oceanu ljubavi...

Možete li se sjetiti neke situacije kada ste istinski voljeli... ili kad ste se osjećali uistinu voljeni?... Možete li u sebi sada oživjeti doživljaj ljubavi? Kakav je vaš unutarnji doživljaj ljubavi? Kakve osjećaje imate u svojemu tijelu?... Toplinu... strujanje... energije... vibracije... valove... neko unutarnje svjetlo? Možete li zamisliti bezuvjetnu, univerzalnu, sveobuhvatnu Božansku ljubav... koja hrani... liječi... oživljava... koja ništa ne traži zauzvrat... koja omogućuje milosrdno prihvaćanje i poštivanje svega i svakoga...

Prije nego što utonete u duboki osjećaj bezuvjetne ljubavi... što se širi cijelim vašim bićem... možete se sjetiti neke vama jako drage osobe... koju istinski volite... osjetiti kako u vama raste osjećaj ljubavi... kako vas ispunjava sve više i više... kako vas u potpunosti preplavljuje... tako da volite sebe bezuvjetno... tako da sebe prihvaćate u potpunosti... da vjerujete u sebe... da sebi možete oprostiti... sebe bolje upoznati i više cijeniti... da možete osjećati kako vas bezuvjetna ljubav iscjeljuje... dovodi u sklad sa samim sobom i drugima...

Bezuvjetna ljubav može se početi širiti izvan vas... postupno ispunjavajući sav prostor u kojemu se nalazite... dok se širi i vaša svijest... s kojom rastete... možete se osjetiti dijelom nje... bezuvjetne ljubavi... koja u vama sve više raste... tako da zračite...

Ljubav nam je dana da je dijelimo s drugima... da nas povezuje... tako da možete zamisliti kako se vaša bezuvjetna ljubav širi na vašu zajednicu... tako da ispunjava sve one koje volite... ili želite voljeti... pa i one koje ne volite... kao i one koji vam rade probleme... Bezuvjetna ljubav oplemenjuje sve one koje dotakne... ona je univerzalna... dostupna svakome od nas... razlog našega postojanja... da volimo i budemo voljeni... da osjetimo moć bezuvjetne ljubavi koja nas iscjeljuje... liječi... spaja u skladnu i jedinstvenu cjelinu sa svima... kad se sve struje bezuvjetne ljubavi spajaju jedinstvenu ljubav...

Zamislite kako se bezuvjetna ljubav širi i zrači po cijeloj našoj domovini... tako da osjećate kako ste povezani s njom... kako sve više raste i širi se... Zamislite kako se bezuvjetna ljubav širi po cijelom planetu... a vi osjećate jedinstvo s njom... pa se širi cijelim Univerzumom... a vi osjećate svoju cjelovitost i savršenstvo života... unutarnji mir... radost življenja i pripadanja... tako da možete razumjeti ljude koji vjeruju da je Bog ljubav... a bezuvjetna ljubav nastanjena u nama Božanska bit našega bića.

Kad poželite otvoriti oči, sjetite se da u sebi uvijek možete potražiti i probuditi bezuvjetnu ljubav koju možete prakticirati u svakodnevnom životu... 


\section{Zaključak}

Uspješno starenje se ostvaruje kroz promociju reziliencije, pri čemu je iznimno važna uloga neuroreziliencije, jer se kroz nju integriraju fiziološka, psihološka, socijalna i spiritualna reziliencija. Uspješno starenje uključuje aktivnosti ne samo na osobnoj i obiteljskoj već i na društvenoj i političkoj razini. S obzirom na to da budućnost ostaje na mladima, a sadašnjost opstaje na starima, u izgradnji zdravog i suosjećajnog društva iznimno je važno poticati programe uspješnog starenja kroz jačanje reziliencije.

\section{Reference}

1. Martin PD, Kelly N, Kahana B, Kahana E, Willcox BJ, Willcox DC, Poon LW. Defining successful aging: A tangible or elusive concept? The Gerontologist. 2015;55:14-25.

2. WHO (World Health Organization). The World Health Report 2002: Reducing Risks, Promoting Health Life. Dostupno na: http://www.who.int/whr/2002.

3. Dossa KS, Soomar SM. Understanding theoretical underpinnings related to aging for an enhanced care of elderly. Nur Heal Car. 2018;1:108-10. doi: 10.32474/ LOJNHC.2018.01.000120.

4. Wang-Michelitisch J, Michelitisch TM. Traditional aging theories: which ones are useful? 2015. Dostupno na: https://arxiv.org.

5. BlackBurn E, Epel E. The Telomere Effect - A Revolutionary Approach to Living younger, Healthier, Longer. London: Orion Publishing Group Ltd, 2017.

6. WHO (World Health Organization). Promoting Mental Health: Concepts, emerging evidence, practice. Geneva, 2005.

7. Rowe JW, Kahn RL. Human aging: usual and successful. Science. 1987;237:143-9. doi:10.1126/science.3299702.

8. Rowe JW, Kahn RL. Successful agin 2.0: Conceptual expansionsfor the 21st century. The Journals of Gerontology Series B: Psychological Sciences and Social Sciences. 2015;70:593-6. doi:10.1093/geronb/gbv025.

9. Tesch-Roemer C, Wahl H-W. Toward a more compregensive concept of successful aging: Disability and care needs. J Gerontol B Psychol Sci Soc Sci. 2017;72:310-8.

10. Fromm E. Umijeće ljubavi. Zagreb: V.B.Z. d.o.o., 2000.

11. Hochhalter AG, Smith ML, Ory MG. Succesful aging and resilience: Appications for public health and health care. U: Resnick B, Gwyther LP, Roberto KA (ur.) Resilience in Aging - Concepts, Research, and Outcomes. Springer Science + Business Media, LLC 2011. p. 15-29.

12. Jakovljević M. Creative, person-centered psychopharmacology for treatment resistance in psychiatry. U: Kim Y-K (ur.) Treatment Resistance in Psychiatry. Spinger Nature Singapore Pte Ltd. 2019. p. 273-293.

13. Jakovljevic M. Resilience, psychiatry and religion from public and global mental health From divide to dialogue and cooperation in the search for humanistic self, compassionate society and empathic civilization. Psychiatria Danubina. 2017;29:238-44.

14. Jakovljevic M. Empathy, sense of coherence and resilience: Bridging personal, public and global mental health and conceptual synthesis. Psychiatria Danubina. 2018b;30:380-4. 
15. Hicks G, Miller RR. Physiological resilience. U: Resnick B, Gwyther LP, Roberto KA (ur.) Resilience in Aging - Concepts, Research, and Outcomes. Springer Science + Business Media, LLC, 2011. p. 89-103.

16. Mlinac ME, Sheeran TH, Blissmer B, Lees F, Martins D. Psychological resilience. U: Resnick B, Gwyther LP, Roberto KA (ur.) Resilience in Aging - Concepts, Research, and Outcomes. Springer Science + Business Media, LLC, 2011. p. 67-87.

17. Jakovljevic M, Borovecki F. Epigenetics, resilience, comorbidity and treatment outcome. Psychiatria Danubina. 2018:30:242-53. https://doi.org/10.24869/psyd.2018.242.

18. Del Campo CMZM, Martinez-Rosas M, Guarner-Lans V. Epigenetic programming of synthesis, release, and/or receptor expression of common mediators participating in the risk/resilience for comorbid stress-related disorders and coronary artery disease. Int J Mol Sci. 2018;19:1224. doi:10.3390/ijms19041224.

19. Del Campo CMZM, Martinez-Rosas M, Guarner-Lans V. Epigenetics of subcellular structure functioning in the origin of risk and resilience to comorbidity of neuropsychiatric and cardiometabolic disorders. Int J Mol Sci. 2018;19:1456. doi:10.3390/ijms19051456.

20. Jakovljevic M, Ostojic Lj. Comorbidity and multimorbidity in medicine today: Challenges and opportunities for bringing separated branches of medicine closer to each other. Medicina Academica Mostariensia. 2013;1:18-28. Psychiatria Danubina 2013 (suppl); 25.

21. Grumbach K. Chronic illness, comorbidities, and the need for medical generalism. Annals of Family Medicine. 2003;1:4-7.

22. Singer M, Bulled N, Ostrach B, Mendenhall E. Syndemics and the biosocial conception of health. Lancet. 2017;389:941-50.

23. Jakovljević M. Duševno zdravlje, psihopolitička kultura i bolesti društva: Kuda ide (hrvatska) psihijatrija? U: Jakovljević M i sur. Duševno zdravlje, kultura i društvo Psihijatrija pred izazovima. Zagreb: Pro mente d.o.o., 2014. p. 27-110.

24. Marasović S, Blažeka Kokorić S. Uloga plesa u unapređenju aktivnog životnog stila i kvalitete života starijih osoba. Rev. soc. Polit. 2014;21:235-54. doi:10.3925/rsp. v21i2.2286.

25. Roth G. Ispleši svoje molitve. Zagreb: Planetopija, 2009. 


\title{
LENS MODEL: PROMOTION OF NEURORESILIENCE AND BRAIN HEALTH IN OLD AGE
}

\begin{abstract}
Promoting healthy and successful aging and the engagement of the elderly in social activities, ie effective prevention of the negative consequences of aging, is extremely important not only as a medical and humanistic, but also as social, economic and political issue. Brain changes that begin in the fifties not only impair memory but also other cognitive functions such as our multitasking abilities, quick processing of information and focusing attention on details. They also reduce our creativity, quality of life, life energy and desire for life. There are many misconceptions and distorted opinions about the brain and aging. Gerontology is increasingly focused on recognizing the specific qualities and abilities of older people and their potential contribution to the community and society. Resilience is a set of protective and salutogenic (neurobiological as well as psychosocial and spiritual) factors that modulate positive outcomes in stressful and unfavourable situations, during aging, and in illness. Up until two or three decades ago, it was believed that our brain creates new neurons only in early age. However, research shows that the brain, thanks to its neuroplasticity, has the ability to change throughout life by creating new neurons and connections between them and even increase its size. Our insights into brain neuroplasticity are expanding, and increasing the resilience of our brain is a major challenge for basic and clinical neurosciences. Individual SWOT (Strength, Weakness, Opportunity, Threat) analysis that includes unique resources and perspectives of love, power, freedom, happiness and meaning is a lens model through which the challenges of old age are refracted, and which predicts prospects for successful aging. The paper presents a lens model for successful aging through the promotion of resilience.
\end{abstract}

Keywords: lens model, neuroresilience, brain health, successful ageing. 